\title{
Obre Solo Sagrado: identidade QUILOMBOLA E CATOLICISMO NA COMUNIDADE de Água Morna (Curiúva, PR)
}

\author{
Liliana Porto, Carolina Kaiss e Ingeborg Cofré \\ Em memória de Dona Pedrolina
}

Este texto tem como objetivo compreender de que maneira a comunidade de Água Morna ${ }^{1}$, localizada no município de Curiúva, PR - elabora uma identidade quilombola a partir da possibilidade de acesso a direitos territoriais coletivos e políticas públicas específicas, garantidos por tal identidade. Esses direitos e políticas são estabelecidos pelas legislações nacional e estadual, e têm por base sua definição como os "remanescentes das comunidades de quilombos". Com efeito, após a promulgação da Constituição Federal do Brasil, em 1988, não somente os negros passam a possuir um status diferenciado - não mais enunciado a partir da perspectiva exclusivamente assimilacionista do Estado - mas também os antigos quilombos ou as comunidades remanescentes de quilombos se tornam matéria de lei e, no último caso, se constituem como sujeito coletivo, com direitos específicos.

Essa situação se consolidou nos mandatos de Lula da Silva (2004-2010). Do ponto de vista mais geral, são indícios de tal fato a criação da SEPPIR (Secretaria Especial de Políticas de Promoção da Igualdade Racial), a consolidação de políticas afirmativas em várias esferas (entre as quais as cotas raciais em universidades e concursos públicos), bem como a recente aprovação do Estatuto da Igualdade Racial ${ }^{2}$. No que diz respeito aos remanescentes de comunidades de quilombos, a definição de políticas públicas próprias e, 
principalmente, a regulamentação e a implementação de ações a fim de possibilitar a titulação coletiva dos territórios dessas comunidades são os marcos de evidência desse reconhecimento (embora não se tenha alcançado um resultado significativo em termos de finalização dos processos). É a partir desse contexto mais amplo que a situação aqui analisada se configura.

As ações na esfera nacional terão repercussões regionais diferenciadas, relacionadas tanto à atuação dos movimentos sociais nos diversos estados quanto a posturas e investimentos distintos dos vários governos estaduais e municipais. O caso do estado do Paraná é bastante ilustrativo. Tendo sua identidade construída como essencialmente branca e moderna - com destaque para a ênfase atribuída à presença na população de descendentes de imigrantes europeus ${ }^{3}$ e do vínculo com a República - o reconhecimento da existência de população negra em geral, e de comunidades quilombolas em particular, se constitui em uma dupla ameaça a tal identidade: por um lado, pela concepção que se propugna do perfil dos habitantes do estado; por outro, pela memória da escravidão que tais comunidades tornam presente. Nesse contexto, representará guinada significativa a constituição em 2004, pelo governo do estado do Paraná, de um grupo inter-secretarial, cuja coordenação é composta por funcionários do estado vinculados ao movimento negro. O Grupo de Trabalho Clóvis Moura teria como objetivo identificar comunidades quilombolas regionais, constituir associações nas mesmas e torná-las alvos de políticas públicas.

É através da atuação desse grupo que a comunidade de Água Morna será reconhecida como quilombola - recebendo certificação da Fundação Palmares - e formará sua associação própria. A partir dessa certificação, o INCRA (Instituto Nacional de Colonização e Reforma Agrária) decide iniciar um processo de identificação, reconhecimento, delimitação, demarcação e titulação de suas terras - juntamente com as de mais seis outros grupos -, o que resultou em um convênio com o Departamento de Antropologia da Universidade Federal do Paraná (DEAN/UFPR). Dessa forma, pelo vínculo institucional universitário, faculta-se às autoras deste artigo, como equipe responsável pela elaboração de seu relatório antropológico, o contato com a comunidade.

A compreensão das respostas dadas por esse grupo à situação acima delineada exige conhecimento dos contextos mais amplos em que se insere a questão quilombola - nas esferas nacional, regional e local - passando por uma discussão sobre o desenvolvimento da legislação em torno dos direitos dos remanescentes de quilombos, a maneira pela qual são implementados, suas consequências no caso específico do estado do Paraná, bem como sobre a forma com que o grupo mobiliza aspectos de sua história e de suas práticas rituais e cotidianas para responder a todo o processo. Processo que apresenta um aspecto crucial para sua compreensão: o deslocamento semântico recorrente com relação ao texto da lei - realizado tanto por agentes estatais quanto por membros do 
movimento social e representantes do meio acadêmico - em que os "remanescentes de comunidades de quilombos" passam a ser definidos como "comunidades remanescentes de quilombos" e, num momento seguinte, "comunidades quilombolas" 4 . Tal deslocamento se expressa na mudança da legislação infraconstitucional e tem consequências significativas para o processo como um todo, entre as quais: a) valorização da organização atual do grupo e de sua memória, em relação à documentação e comprovação de uma ocupação histórica de longo prazo do território; b) ênfase em uma resistência à opressão sofrida, em sentido mais amplo, em contraposição a uma perspectiva mais restrita de luta contra o sistema escravista; c) destaque de uma perspectiva do caráter comunitário dos grupos negros em questão, em que um estereótipo de comunidade relativamente igualitária, harmônica, coesa, solidária, com projetos políticos comuns (em síntese, uma visão romântica - e, pode-se dizer, cristã - de comunidade) é acionado. Os dois primeiros aspectos terão, entre outros impactos, influência direta no lugar primordial ocupado pelo relatório antropológico no processo de regularização fundiária. Já o terceiro traz consigo uma série de expectativas com relação às respostas que as comunidades devem apresentar face ao processo de afirmação de uma identidade relativamente coesa e de regularização (necessariamente por titulação coletiva ${ }^{5}$ ) do território. A primeira parte do texto tem por objetivo explorar esse contexto geral, e fornecer subsídios para a compreensão das respostas dadas a ele pelos moradores de Água Morna ao (re)elaborar, frente à demanda externa, sua própria história e identidade.

$\mathrm{Na}$ segunda parte do texto, analisaremos os aspectos da memória e das práticas sociais atuais que são mobilizados pelos membros do grupo a fim de definir sua identidade quilombola, percebendo tal elaboração como simultaneamente resultado de um jogo político novo e de sua leitura e reação a ele a partir de elementos preexistentes - com destaque à mobilização de discursos e práticas vinculados ao catolicismo popular. Em outras palavras, embora os moradores de Água Morna não se percebessem como quilombolas, e não tivessem, no período anterior à atuação do GT Clóvis Moura e do INCRA, necessidade de delinear claramente sua identidade no plano discursivo, são memórias, práticas e visões de mundo prévias que possibilitarão que respondam de maneira bem sucedida às questões que o novo contexto lhes coloca - o que não ocorre com o mesmo sucesso no caso de algumas das demais comunidades estudadas pelos antropólogos vinculados ao convênio UFPR/INCRA. Acrescentese que tais memórias, práticas e visões de mundo têm por base a religiosidade católica do grupo e o vínculo de tal religiosidade com a percepção do território e do próprio grupo como portadores de uma sacralidade (que fundamenta as leituras sobre a expropriação territorial e as possibilidades de resistência a ela). 


\section{Contexto: legislação, política e religiosidade}

A adoção, na Constituição Federal de 1988, de uma perspectiva da nação como plural, rompendo com a visão assimilacionista até então prevalente, resulta em uma substancial ampliação de direitos coletivos e direitos difusos frente a contextos anteriores. No que tange a grupos afrodescendentes com características culturais específicas, não somente há o reconhecimento de seu valor a partir da importância a eles atribuída na formação nacional (destaque para os artigos 215 e 216), mas também a garantia do direito de propriedade definitiva aos "remanescentes de comunidades de quilombos que estejam ocupando suas terras" (art. 68 dos $\mathrm{ADCT})^{6}$. No entanto, inúmeros entraves foram, e são, enfrentados por esses grupos ao buscarem a aplicação da norma constitucional.

Aqui, dois deles serão destacados. Em primeiro lugar, a lentidão no processo de regulamentação através de legislação infraconstitucional. Com efeito, observase o transcorrer de mais de uma década até que ocorresse uma primeira regulamentação do art. 68 pelo Decreto Presidencial 3912/2001. Esse, contudo, ao enfatizar a noção de "remanescentes" - informado, portanto, por uma perspectiva em que o deslocamento semântico que indicamos na introdução não orienta o texto da lei - definiu como passíveis de reconhecimento apenas as terras que "eram ocupadas por quilombos" em 1888 e assim permaneciam até 05 de outubro de 1988, e não explicitou a definição de quilombo com que operava.

Surge, então, o segundo entrave: as exigências do Decreto 3912 demonstraram ser excessivamente restritivas, mas também incompatíveis com a maneira pela qual negros brasileiros moradores de áreas rurais lidam com a memória da escravidão - e, consequentemente, com a possibilidade de construírem um discurso identitário quilombola que se adequasse às exigências legais. Ao menos pelo que se explicita através de estudos realizados na região Sudeste (cf. Rios \& Mattos 2005; Rosa 2004; Porto 2007).

Nos vários casos considerados pelas autoras, há uma tendência a se retratar o sistema escravista como marcado pela desumanização do negro, descrevendo o tratamento a ele dispensado como igual ou mesmo inferior ao de animais. Sendo assim, a memória de antepassados escravos, quando ocorre, em geral remete ao período em que eles deixaram de sê-lo. No entanto, o peso da lembrança da desumanização leva a que vários grupos optem por desvincular a experiência da escravidão de seu passado, através dos seguintes expedientes: 1) referência a antepassados cuja história só se inicia com o começo da comunidade, quando a liberdade já está instaurada; 2) negação de um passado anterior aos avôs cuja memória seja relevante - sendo o "tempo dos avôs" a referência última. Torna-se, portanto, muito difícil a datação do início da ocupação territorial pelo grupo, principalmente nos inúmeros casos em que não há nenhum documento disponível anterior ao século XX. 
Em alguns contextos, até mesmo a autodefinição da comunidade como negra é problemática, devido ao processo que Rosa (2004) denomina como "racialização da escravidão" no Brasil, que resulta no estabelecimento de uma sinonímia entre negro e escravo, provocando simultaneamente a desvalorização do primeiro termo - que em alguns casos pode constituir até mesmo um xingamento - e a opção por denominações como, por exemplo, "morenos" ou "escuros". Um depoimento de morador da comunidade do Espinho (localizada no município de Gouveia, MG) citado pela autora, é aqui bastante esclarecedor:

Negro é quem serviu no escravidão. A gente é a cor da cor, mas só que o pessoal fala nêgo, mas nós nunca fomo assim [...] Nêgo de trabaio. Os nêgo que o pessoal dizia é quem serviu no escravidão; da minha família ninguém nunca trabalhô servindo o escravidão, mas pôr causa da cor o povo fala nêgo, mas não é. Nêgo é quem serviu no escravidão (apud Rosa 2004:115).

O trecho indica as dificuldades de se afirmar o direito por um território que se constitui como espaço da liberdade através das referências a um contexto de desumanização e de negação total dessa liberdade - o que, em certa medida, se colocava como exigência do Decreto 3912. Assim, sua revogação pelo Decreto 4887/2003 implica não somente a possibilidade de que os grupos se construam e consolidem como sujeitos de direito - ao reforçar uma perspectiva fundada na contemporaneidade e em temas que são símbolos da resistência dos próprios grupos - mas também expressa a vitória política de uma perspectiva relacionada ao deslocamento semântico anteriormente citado. Destaque-se o art. $2^{2}$ que, pela primeira vez na legislação, apresenta uma definição explícita para a noção de "remanescentes de comunidades de quilombos":

Art. $2^{\circ}$ - Consideram-se remanescentes das comunidades dos quilombos, para os fins deste Decreto, os grupos étnico-raciais, segundo critérios de auto-atribuição, com trajetória histórica própria, dotados de relações territoriais específicas, com presunção de ancestralidade negra relacionada com a resistência à opressão histórica sofrida (Brasil 2003).

Gostaríamos de apontar alguns aspectos centrais dessa definição. Em primeiro lugar, a temporalidade deixa de ser o principal fator na postulação do direito, ao se afirmar como base a resistência a uma opressão histórica não identificada de maneira restrita (assim, a referência explícita à escravidão não se faz mais necessária), mas também ao conferir à autoatribuição papel fundamental na definição do grupo como remanescente de quilombo. Depois, 
observe-se que a existência de uma trajetória histórica própria, de relações territoriais específicas e da presunção à ancestralidade negra ${ }^{7}$ são elementos básicos na caracterização proposta.

As mudanças na legislação podem ser vistas tanto como resultado quanto como fortalecimento do deslocamento semântico proposto - em que os remanescentes de comunidades de quilombos são pensados a partir da noção de "comunidades quilombolas". Nesse processo, os problemas indicados quando se abordou o Decreto 3912 não se diluem simplesmente, mas são substituídos por outros. Dentre eles, uma exigência não explicitada de que os grupos negros que se auto-reconhecem como quilombolas elaborem um discurso identitário que aponte não somente o pertencimento de seus membros a uma coletividade percebida como específica e diferente do entorno, mas também que essa identidade se conjugue com formas particulares de sociabilidade - em que os aspectos de coesão são valorizados em detrimento de tensões - nas quais elementos como trabalho comunitário, espaços de uso compartilhado, projetos políticos comuns e uma relação romantizada com o passado e o ambiente sejam ressaltados ${ }^{8}$. Em outras palavras, reconhece-se o direito à diversidade, mas em certa medida se exige da diversidade que se encaixe no modelo de diversidade considerado por agentes externos (tanto vinculados ao Estado quanto a organizações da sociedade civil) como adequados. Sendo assim, a adesão aos processos de reconhecimento por direitos é vista como algo óbvio, e, quando a mesma não ocorre, como resultado de uma situação de ignorância, de incompreensão do grupo em torno das propostas estatais.

Buscamos, ao considerar um caso bem sucedido de resposta ao processo de regularização fundiária iniciado pelo INCRA, realizar uma reflexão em torno das condições que propiciaram esse sucesso - que, muito longe de serem óbvias, dizem da forma de constituição de uma visão de mundo particular da comunidade de Água Morna, em que uma vivência específica do catolicismo e sua inscrição no território tradicional do grupo fundamentam sua coesão e capacidade de elaboração de um discurso comum, que conseguiu superar quaisquer dissensões internas. Com efeito, no caso abordado, a possibilidade de registrar, através da elaboração do relatório antropológico, sua interpretação da história, suas práticas e sua religiosidade particular (que lhe confere uma percepção de sacralidade do grupo frente aos "de fora") é tanto um estímulo ao processo de adesão à pesquisa no local quanto um resultado valorizado em si mesmo.

Antes, contudo, de passar à análise específica do caso de Água Morna, cabe fazer algumas considerações sobre os impactos do contexto legal acima delineado no Paraná, pois, como indicamos, ele não possui a mesma repercussão que em outras regiões do Brasil.

Nesse estado, até o início do século, devido à forma de construção da identidade regional, havia um silenciamento sobre a presença negra em geral, 
e sobre grupos rurais negros em particular. Somente a comunidade Invernada Paiol de Telha apresentava uma situação política de conflito e organização com reconhecimento regional. Boa parte das atuais comunidades quilombolas com certificação de auto-reconhecimento, já concluída ou em andamento9 ${ }^{9}$, iniciou seu processo de organização com vistas à certificação, e mesmo incorporou a definição de quilombolas ${ }^{10}$, a partir da atuação do GT Clóvis Moura, já mencionado. Este apresenta simultaneamente os objetivos de identificar comunidades negras no interior do Paraná, organizar suas associações, estimular a autodeclaração como quilombolas e facultar a elas o acesso a programas governamentais, conjugando ações especificamente estatais com um discurso marcado pelo perfil militante de seus principais membros. Além disso, como resultado das dificuldades por eles apresentadas em lidar com o fato de se relacionarem com comunidades diversas e pouco conhecidas, o GT opera com uma perspectiva estereotipada do perfil ideal de (ou adequado a) grupos quilombolas - aspecto não exclusivo ao grupo, mas que marca a maior parte dos responsáveis pela implementação de políticas públicas relacionadas aos direitos de grupos sociais específicos.

O Grupo Clóvis Moura, como dissemos, se constitui em 2004. Em seus primeiros anos de atuação aumenta significativamente seu tamanho, os recursos a que tem acesso e o poder político dentro do Paraná. Posteriormente, com o início do processo de regularização fundiária de algumas comunidades pelo INCRA, bem como com o surgimento de questões internas e com a ampliação das esferas do governo estadual relacionadas à temática, o grupo sofre uma perda de poder e de recursos significativa ${ }^{11}$. De uma perspectiva inicial da existência de doze grupos negros rurais no estado ${ }^{12}$, o levantamento do GT chegou a uma lista de mais de oitenta - predominantemente rurais, mas alguns urbanos - durante o período. Embora não fosse de sua competência o procedimento administrativo de titulação dos territórios quilombolas, realiza diversas ações não apenas no sentido de pressionar o INCRA a abrir tais procedimentos, mas também de acelerar o processo (alternando experiências bem sucedidas com intervenções responsáveis por intensificar conflitos locais).

Para as comunidades, o resultado de todo este contexto político é a necessidade de enfrentarem uma nova realidade complexa, com mudanças significativas frente a sua situação anterior marcadas por: 1) valorização de sua existência e memória; 2) acesso a recursos diferenciados e necessidade de distribuição interna de tais recursos; 3) intensificação do contato de representantes dos grupos com representantes de outros grupos quilombolas e agentes estatais e do movimento social (tanto nas visitas de tais agentes às comunidades quanto nos inúmeros eventos realizados pelo Estado e por ONGs); 4) exigência da elaboração de uma identidade quilombola e de definições mais precisas sobre limites da comunidade; 5) geração ou ampliação de conflitos locais; e 6) 
reestruturação das relações com moradores locais não quilombolas (principalmente a partir do procedimento que visa à titulação, quando eles passam a ser vistos por proprietários e ocupantes como ameaça a seu direito a terra e à permanência no lugar).

Em outras palavras, a projeção que adquirem as comunidades quilombolas dentro do Paraná ampliou sua visibilidade e acesso a recursos, mas simultaneamente gerou a necessidade de elaboração de um discurso identitário minimamente coeso e coerente, inclusive capaz de explicitar quais os critérios de pertencimento ao grupo, bem como da definição de representantes que pudessem realizar a mediação com demais agentes políticos envolvidos na questão quilombola, e de readequação das relações com os moradores locais não quilombolas frente ao novo contexto. As respostas dadas a tais exigências não são simples nem ocorrem da mesma maneira em todas as comunidades, podendo gerar graus diferenciados de tensões e conflitos, tanto externos quanto internos, mas são sem dúvida estruturadas pela organização prévia de práticas, memórias e visões de mundo do grupo: fatores cruciais na definição das possibilidades de tais respostas.

Arruti (1997), ao abordar o tema do reconhecimento de comunidades remanescentes em período anterior ao dessa regulamentação, aponta como tal denominação implica na elaboração de uma identidade antes inexistente, embora composta por uma adequação entre elementos elencados pelos agentes políticos externos como relevantes e aspectos selecionados a partir de uma matriz de hábitos e crenças das comunidades em questão. Assim, se por um lado identifica tal processo como uma etnogênese, por outro afirma a necessidade de assumirmos que a dinâmica é uma característica da vida social, e que longe de descaracterizálos, essas respostas apontam o potencial desses grupos de ressignificar o passado frente a um quadro político novo. A descrição das consequências da adoção da nova identidade pelo autor sintetiza o panorama do Paraná anteriormente esboçado:

No processo (na maioria - senão na totalidade das vezes conflituoso) de nomeação de um grupo como "remanescente" produzse uma série de mudanças que atingem aquelas comunidades, tanto na sua relação com os que as rodeiam - sejam as populações vizinhas, os poderes locais ou os aparelhos de Estado -, quanto nas relações entre seus próprios atores, com acomodações, disputas e muitas vezes a própria criação de chefias e formas de ordenamento político, com a alteração dos significados atribuídos às festas e rituais, com a reelaboração da memória e com a alteração do status dos guardadores da memória, que passam a desempenhar um papel sem precedentes na vida do grupo. Apesar das exigências do termo, os 
"remanescentes" não são sobras de antigos quilombos prontos para serem identificados como tais, presos aos fatos do passado por uma continuidade evidente e prontamente resgatada na "memória coletiva" do grupo.

Independente de "como de fato foi" no passado, os laços das comunidades atuais com grupos do passado precisam ser produzidos hoje, através da seleção e recriação de elementos da memória, de traços culturais que sirvam como os "sinais externos" reconhecidos pelos mediadores e o órgão que tem a autoridade de nomeação. As diferenças que podiam até então distingui-los da população local na forma de estigmas passam a ganhar positividade, e os próprios termos "negro" ou "preto", muitas vezes recusados até pouco tempo antes da adoção da identidade de remanescentes, passam a ser adotados. As fronteiras entre quem é e quem não é da comunidade, quase sempre muito porosas, passam a ganhar rigidez e novos critérios de distinção, genealogias e parentescos horizontais passam a ser recuperados como formas de comprovação da inclusão ou não de indivíduos na coletividade. Ao mesmo tempo, a maior visibilidade do grupo lhe dá uma nova posição em face do jogo político municipal e, por vezes, estadual. Enfim, a adoção da identidade de remanescentes por uma determinada coletividade, ainda que possa fazer referência a uma realidade comprovável, é, com muito mais força, a produção dessa própria realidade (Arruti 1997:23).

No caso aqui analisado, a etnogênese apontada por Arruti tem por base a mobilização de um discurso religioso e de seu vínculo com o território, como veremos. Tal religiosidade, entretanto, não é exclusiva à comunidade de Água Morna - embora as relações entre ela, a constituição do grupo e o território o sejam.

Assim, após abordar a legislação e a política que constituem parte significativa do contexto a partir do qual Água Morna sistematiza seu discurso identitário quilombola, esboçamos algumas características do catolicismo popular paranaense (que se estende, em certa medida, para parte significativa da Região Sul do Brasil), base de tal discurso. Destacamos a presença de São João Maria (localmente denominado São João de Maria), seu perfil sacralizador - tanto de espaços quanto de pessoas - e profético, e a ausência de um registro claro de sua morte (que, em certos casos, implica na negação dessa morte).

O monge João Maria, conhecido como São João Maria, é normalmente apresentado na bibliografia como uma síntese de três figuras históricas distintas que percorreram a região de meados do século XIX ao início do século XX: João Maria d'Agostini, João Maria de Jesus e José Maria (o último conhecido por ser 
uma figura central na deflagração da Guerra do Contestado). Todos eles têm em comum a figura de andarilho barbado, que através de sua peregrinação pelo território sacralizava espaços, realizava curas e fazia profecias. No entanto, curiosamente, as referências ao santo não canônico em estudos acadêmicos estão normalmente vinculadas aos conflitos ocorridos no início do século XX na região contestada entre Paraná e Santa Catarina (cf. Machado 2004; Cabral 1960; Gallo 2008). Algumas vezes, uma das fotografias do santo, encontrada como objeto de culto na atualidade, é utilizada como capa ou primeira imagem de livro sobre o tema - como é o caso de Machado (2004) e Fraga (2009). Essa fotografia, embora represente um personagem tido como único, nunca representa José Maria, o monge cujo assassinato está vinculado ao início dos conflitos do Contestado. A forma de abordar esse personagem histórico/mítico tem como resultado sua localização muito precisa tanto no espaço quanto no tempo restringindo sua influência ao oeste de Paraná e Santa Catarina nas primeiras décadas do século XX. Além disso, traz consigo a ideia de que seu culto estaria restrito a populações caboclas pouco escolarizadas e urbanizadas que viviam na região naquele período.

A pesquisa da presença da memória do monge/santo na contemporaneidade, no entanto, indica um quadro distinto: em primeiro lugar, a referência tanto ao Contestado quanto a José Maria é praticamente inexistente entre aqueles que têm "devoção" a São João Maria ${ }^{13}$; depois, ele é normalmente descrito como alguém que compartilhou com os sujeitos/grupos experiências comuns, e através delas sacralizou olhos d'água e espaços sagrados (onde na atualidade são realizados batizados, peregrinações e curas), bem como pessoas (experiências de contato com São João Maria são recorrentes nos relatos de benzedeiras sobre seus poderes - cf. Braga 2009 e o depoimento de dona Dejair, citada na segunda parte deste texto). Cabral (1960), ao abordar a presença da memória de João Maria em regiões próximas àquela em que ocorreu a Guerra do Contestado, assim a descreve (descrição que permanece esclarecedora meio século depois, e pode ser atribuída a uma região mais ampla):

Entretanto, percorra-se o sertão catarinense e parte do paranaense [...] e inquira-se sobre João Maria.

E se ouvirá, talvez com surpresa, sobre o Santo - pois ele ainda é santo para o povo da região, o São João Maria. As palavras mais respeitadoras do seu pitoresco vocabulário o homem do sertão buscará para honrar-lhe a memória. E contará episódios de sua vida, da vida do peregrino inofensivo, que nunca desejou a luta, embora a tivesse previsto com uma clarividência de surpreender, do peregrino que pregava e praticava o bem e que se não era um rigoroso observante dos mandamentos da Igreja, praticava os de Deus [...]. 
E, se o pesquisador for além, verá que, assim como ele é considerado santo pelo sertanejo, santas são as cruzes que plantou, santas as árvores sob as quais pousou, milagrosas as águas que apontou às abluções dos seus amigos e nas quais se dessedentou. Tudo o que se refere à vida de João Maria ainda é, ali, santificado pela presença de sua lembrança (Cabral 1960:8-9).

O destaque adquirido pelos monges João Maria, e que se mantém através da figura histórico/mítica de São João (de) Maria, é diretamente vinculado a sua identificação com uma perspectiva de mundo característica do universo rural do sul do país, universo que reage à alteração da ordem social provocada pela expansão capitalista e pela concepção da terra como recurso produtivo e propriedade que tem seu valor dado pelo mercado. As profecias atribuídas ao monge remetem a experiências de expropriação territorial e mudança de forma de vida enfrentadas por grupos tradicionais que habitam na região, resultantes da expansão do capitalismo - tanto pela ação depredatória das madeireiras quanto pelo modelo de produção adotado pelos grandes fazendeiros e pelo agronegócio. Falam, assim, de gafanhotos com dentes e asas de aço (as motosserras; cf. Gallo 2008:125), de campos cobertos por voador, como teias de aranha (cercas de arame; cf. Marcon 2008).

Nesse contexto, sua mobilização no processo de construção identitária quilombola de Água Morna reflete, simultaneamente, como o grupo constrói sua perspectiva do passado e do presente a partir de seu vínculo com o contexto religioso tradicional da região, mas, ao mesmo tempo, o faz de uma maneira muito específica, que os define como os legítimos guardiães da sacralidade tanto do território quanto da maneira com que vivem sobre ele.

\section{A comunidade de Água Morna: catolicismo popular como eixo de identidade}

A comunidade de Água Morna consiste em um caso interessante para se pensar um processo bem sucedido de etnogênese, no sentido atribuído ao termo por Arruti. Embora a identidade de quilombola tenha sido imposta externamente, e com ela a denominação dos moradores locais como negros, os membros do grupo (principalmente do que se poderia considerar seu eixo central) não apresentam maiores empecilhos a sua nova caracterização. Ao contrário, a possibilidade de explicitar sua condição específica dentro do contexto regional, bem como de tornar públicas e legítimas suas práticas e concepções de mundo - principalmente aquelas relacionadas às histórias de expropriação por eles sofridas, que estão diretamente vinculadas a sua condição particular de católicos e respeitadores dos preceitos divinos, sistematicamente desrespeitados pelos 
opressores - foi em si mesma um estímulo significativo para que aderissem aos projetos estatais. É importante lembrar, porém, que tal identidade também se apresenta como um instrumento relevante na garantia de acesso a políticas públicas voltadas diretamente a essas comunidades - que na prática são muito menos efetivas que no discurso estatal -, bem como uma base para a possibilidade de recuperação do território ancestral (ainda que venha se mostrando cada vez mais remota).

A denominação de quilombola não implica na adesão a uma identidade genérica, nem mesmo sua identificação com a outra comunidade quilombola do município - denominada Guajuvira, e que resiste claramente ao processo de regularização fundiária pelo INCRA ${ }^{14}$. Ao contrário, mesmo os direitos potencialmente adquiridos são lidos a partir da concepção do passado, da relação com os ancestrais e com o território. Assim, a expectativa de ter novamente controle sobre a área da antiga Fazenda Pinhal, titulada em nome do ancestral Maurício Carneiro do Amaral, é interpretada frente à fala de um dos "antigos", o sr. Otacílio, pai da atual líder religiosa e porta-voz da comunidade na esfera local, de que as terras da fazenda um dia voltariam às mãos deles. Segundo Nice, neta de Otacílio, o avô falava que "isso um dia podia correr sangue, mas que as terras iam voltar nas mãos dos verdadeiros donos; ele podia não alcançar, mas um dia ia acontecer". É difícil dizer se esta é a interpretação do presente a partir de uma fala do passado, ou a reelaboração do passado e da postura dos ancestrais a partir do tempo presente. Em qualquer dos casos, contudo, reflete uma perspectiva profética que marca a sabedoria dos antigos, entre os quais, como veremos, se inclui São João de Maria. Em outras palavras, esse diálogo entre passado e presente é fundamental tanto para sustentar os processos pelos quais o grupo passa no cotidiano quanto para fortalecê-los frente aos conflitos com proprietários não quilombolas e com a elite política local (agravados após o início da regularização) e a espera que precisarão enfrentar.

Inicialmente, cabe aqui fazer uma breve descrição da organização social da comunidade. Composta em 2009 por 48 pessoas, distribuídas em 16 moradias, Água Morna possui uma característica singular: apresentando 15 das 16 moradias com pelo menos um morador descendente da ancestral Benedita, pode-se identificar uma das casas como o eixo organizador da comunidade, havendo confluência tanto do parentesco quanto da organização política do grupo para ela. Essa família é composta por um casal de primos de gerações diferentes, sendo o marido, Seu José, neto, e sua mulher, dona Dejair, bisneta de Benedita. As demais casas do que seria o núcleo principal da comunidade, e que ocupam boa parte de suas terras são: da mãe do marido e de seus três irmãos ${ }^{15}$, de cinco filhos do casal (duas filhas casadas com primos, cujos pais já morreram), do irmão da mulher (no mesmo terreno mora uma filha dele com a família). Não possuindo a mesma importância para a comunidade temos duas casas de irmãs 
dos primos/genros do casal que têm problemas mentais, uma do genro de um irmão do marido com o neto (a filha o abandonou), e de um casal não parente (cujo marido, negro, é da comunidade de Guajuvira, também situada no município).

Dona Dejair também tem um papel significativo na comunidade por se constituir na principal liderança religiosa do grupo - ela é a pessoa que domina os conhecimentos sagrados mais relevantes, entre os quais as rezas antigas, que se distinguem das rezas dos eventos oficiais da Igreja. Também é ela quem controla ritos como a encomenda, em que os membros da comunidade, no período da Quaresma, realizam um circuito de rezas envolvendo as casas dos moradores e cruzes de antepassados ou de antigos. Embora sua liderança religiosa comece hoje a ser compartilhada com uma das duas filhas casada com primo, Lenir, e com uma nora, Maria, isso ocorre somente em eventos religiosos não tradicionais, sendo o lugar de dona Dejair como guardiã da religiosidade local inquestionável, e garantido por um relato em que ela é sacralizada pelo mesmo agente - São João de Maria - que sacraliza as terras da comunidade ${ }^{16}$. Acrescente-se que os objetos mais fortemente significativos do passado, trazidos pela ancestral do remoto local de onde vem, são $\operatorname{católicos}^{17}$ : a pequena imagem de N. Sra. da Conceição, que teria sido dada a Benedita por sua mãe Francisca, e que até 2009 era cultuada no dia 7 de dezembro por sua filha Pedrolina, a mais velha moradora local, então com 94 anos $^{18}$; e o Vinagre de Bom Jesus, importante remédio cuja história está vinculada a um dos mais violentos casos de expropriação de terras da memória do grupo.

O catolicismo é base dos valores sociais que orientam a comunidade, como é explicitado no seguinte trecho de de dona Dejair (que também explicita o caráter profético desse catolicismo):

E a gente foi se criando vendo como que era a criação deles, rezando, eles faziam as rezas deles, se juntavam toda a comunidade pra rezar junto, as famílias, toda vida. [...] É bíblico que no final dos tempos... tempo vai e tempo vem. O tempo de mais saúde, de mais respeito já foi. Era menos o povo no mundo, mas era de mais fé. Um povo religioso, um povo que rezava, um povo que acreditava em Deus. Porque os mais velhos aturaram cem, cento e poucos anos, mas porque eles acreditavam no Pai, eles acreditavam no que eles faziam, e hoje não, hoje está tudo mudado as coisas. Nós se criamos assim: rezando com pai e a mãe, os avós da gente. Eles colocavam as crianças junto com eles na hora da oração e ali era hora de silêncio, ninguém conversava, ninguém pulava, ninguém gritava, prestava atenção ali até terminar. Quando eles encerravam a reza daí eles diziam "Agora pode ir brincar, beijem o santo ali ou a 
santa". Ensinavam nós a fazer o nome do pai, o santo sinal da cruz que hoje é difícil quem faz, eles ensinavam a gente e depois a gente foi aprendendo a cantar com eles nas rezas, nas recomendas. (Busque, Rute, lá a matraca e traga aqui pra ela conhecer). A gente aprendeu a cantar, a rezar. As mãe veia falavam assim: "Precisa aprender, meu filho, nós não atura toda vida, nós não ficou pra semente, um dia vocês não vão ter nós junto. Vocês precisam aprender pra vocês saberem seguir o caminho de Jesus" (Depoimento de dona Dejair, 30/01/2007).

Essa força da religiosidade é reconhecida por todos os moradores locais, e se expressa inclusive na maneira como as crianças concebem sua comunidade. Ao serem solicitadas a desenhar Água Morna, destaca-se o lugar da igreja na maior parte das imagens produzidas, como pode ser visto nos seguintes desenhos:

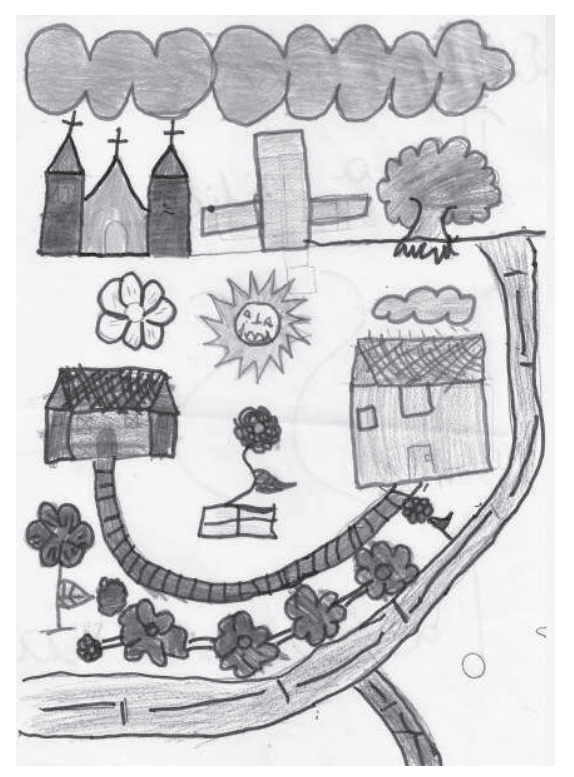

Figura 10: Desenho de Água Morna - Kauana, 9 anos 


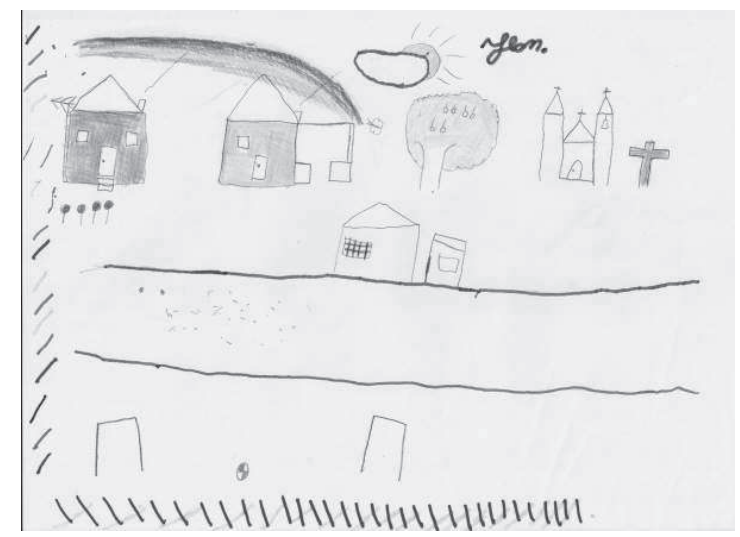

Figura 11: Desenho de Água Morna - Jean, 11 anos

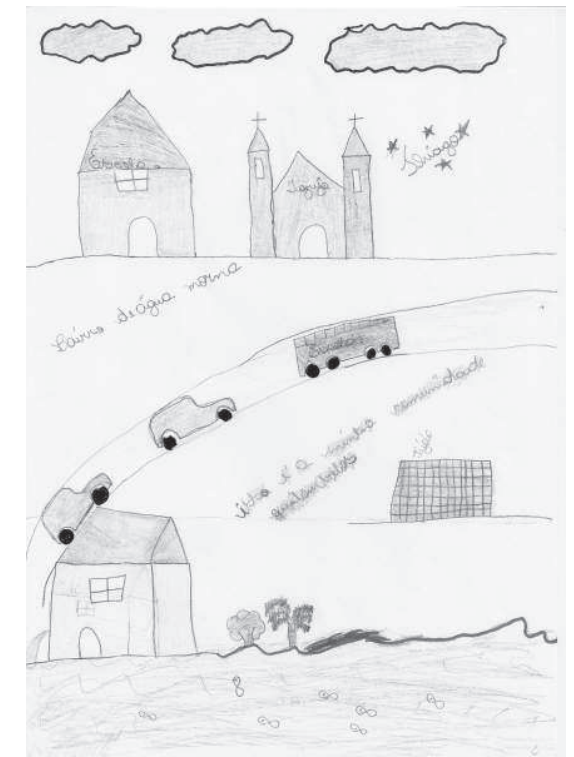

Figura 12: Desenho de Água Morna - Thiago, 11 anos 

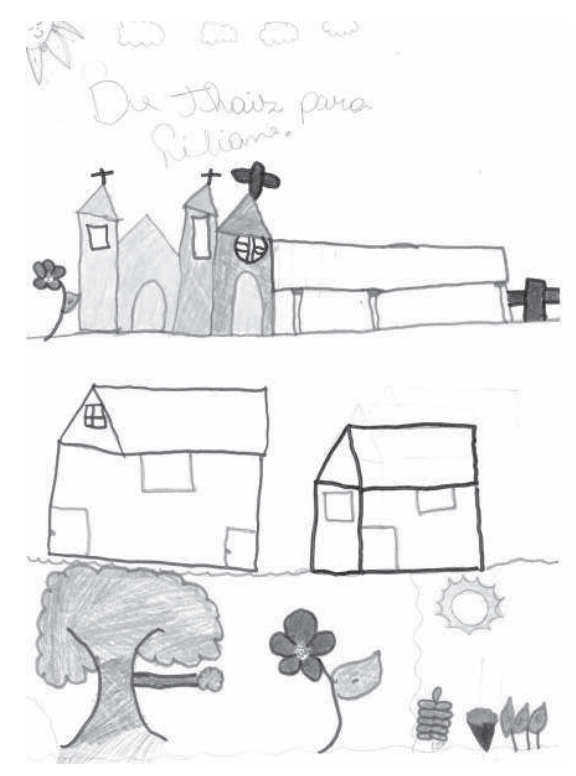

Figura 13: Desenho de Água Morna - Thaís, 11 anos

Nestas imagens, é ilustrativo perceber que a presença da igreja é uma constante (que se repete também em outros desenhos não reproduzidos aqui), ocupando sempre o plano de cima da folha. Trata-se de um elemento que simbolicamente define o espaço coletivo. Acrescente-se que essa é uma visão que não se restringe a um grupo etário ou de gênero. Tanto crianças quanto adultos, homens ou mulheres são unânimes não somente em afirmar a importância das práticas e crenças católicas do grupo, mas também em vincular o espaço da comunidade à área de uso comum em que a igreja ocupa lugar de destaque, embora o conjunto também conte com o campo de futebol, o barracão de festas e a escola.

Cremos, contudo, que os relatos em que a importância da religiosidade católica - e de um catolicismo próprio, marcadamente distinto daquele que é praticado pelas elites da igreja no município (identificadas como preconceituosas em relação às práticas do grupo, intolerantes) - são aqueles que falam do território, do processo inicial de ocupação pelos ancestrais e da expropriação posterior a que são submetidos. Através desses relatos percebe-se que o sucesso das respostas de Água Morna ao contexto político externo não é, em nada, autoevidente, mas a expressão de concepções de sua própria história e de sua dinâmica interna que são mobilizadas para responder às novas questões enfrentadas pelo grupo. Concepções e dinâmicas que não se restringem à memória, mas se inscrevem no território. É assim que, no relato de dona Dejair, a terra de Água Morna é vista 
como "terra santa", pois ela não apenas retira das agruras da escravidão, mas também permite que cumpram suas obrigações religiosas. Além disso, os ancestrais já chegam acompanhados de Nossa Senhora da Conceição, que é uma intercessora do sagrado que contribui para sua libertação:

P: E a senhora falou dessa coisa da senzala e dos escravos, o quê a senhora sabe da escravidão?

D: Ah, eu sei como diz essa história que a mãe veia Benedita falava. Ela falava pras outras mãe veia, mas a gente prestava atenção, que eles sofriam bastante, e ela contava que tinha que fazer as coisa assim quando o patrão mandava, quando ele mandava já tinha que tá lá cuidando, era assim. Os homem lá no serviço, arrastá pau, as muié ia cozinhá e se num fosse fazer as coisa assim, ah, fazia proposta que se num queria fazer ia derramar gordura nos pé. Gordura quente. É... foi muito sofrida, mãe veia contava. Ela diz "Oia mia fia, meus fio, graças nós tá com vida, ocês nunca percam a fé que Deus ensinou, o que Deus ensinar é o necessário de nós viver. Isso porque a vida é boa se nós tiver paciência, nós tê humildade, isso porque senão ninguém vive, morre", ela falava assim. Eles sofrero muito. Do tempo da mãe dela, a falecida mãe Chica, minha avó da minha sogra, né, era o tempo que eles sofriam. Muitas vez tinha reza assim, porque foi um povo religioso, o patrão num deixava ir, tinha que trabaiá. Bem no horário de rezar eles tinham que tá trabaiando. Era assim, daí eles rezavam na casa. Eles sofrero bastante. Aqui esse lugar nosso, eu creio que é uma terra sagrada, é uma terra santa, porque quando os vovô entraro aqui, já eles trouxeram Nossa Senhora, acompanhou eles na caminhada. Fazendo a devoção pra se livrar. Nessa parte você pensa, me entende, a mãe veia Benedita morreu com 120 anos, nesta terra aqui. Agora o vô Maurício eu num sei com que idade ele morreu. E ele morreu aqui (Depoimento de dona Dejair, 31/07/2007).

A sacralidade inicial se desdobra em momentos posteriores, quando o território e os ancestrais são novamente sacralizados pela presença de São João de Maria, que compartilha com eles seus ensinamentos e sua companhia ao longo de três dias. Embora longo, o relato de dona Dejair sobre o acontecido é muito significativo:

P: A primeira coisa que eu queria que a senhora contasse pra gente, dona Dejair, é da andança de São João de Maria aqui pelas terras. Como é que foi? 
D: É assim, como a minha bisavó contava pra nóis, que quando eles entraram aqui que era sertão, mato, mato livre, então o profeta veio e deixou uma fonte ali em... que falava Caetê nessa época, não falava Curiúva... que hoje é Curiúva. Daí ele veio e se acampou ali na Água Grande, nessa mesma terra, e daí lá ele ficou três dias naquele lugar. Tem o olho d'água dele lá adonde que tem a nossa capela, tem o cruzeiro.

P: Ah... logo ali onde tem a capela mesmo?

D: Não, lá na Água Grande. E aí o nosso avô vinha, vinha conversar com o servo ali né? Ficava até tarde da noite conversando com ele, e ele explicou tantas coisas boas que depois a nossa avó contava pra gente, dessa época. Ela contava que ele explicou pra eles que esse nosso tempo ia ser uma correria, diz "Oh, meu filho, vai tempo e vem tempo. Tem o tempo de bastante pasto e pouco rasto", foi essa época que não existia essa multidão de gente que existe hoje, era menos o povo no mundo. Vizinho era um longe do outro e tudo sempre tinha o tempo de se visitar, de conversar. Daí ele falou "Oh, e vai vim o tempo de bastante rasto e pouco pasto". É esse tempo que tamo agora. Milhões e milhões de pessoas, uns vai e outros vem, é bastante rasto e pouco pasto, né? Quantas pessoa não sofre? Passa fome, outros não têm um pano pra vestir, né? Existe hoje, nesta época agora que ele explicô, tempo de bastante pasto e pouco rasto vai terminar, terminou. E vem o tempo de bastante rasto e pouco pasto. Quer dizer que agora o povo é muito e a maioria sofre, né? A maioria sofre. E ele explicou: "E vai chegar um dia, vocês podem não alcançar esse tempo, o que for tomado e o que for escondido debaixo da terra, a terra vai soltar pra fora. Vai chegar esse dia". Tudo isso ele explicou pro casal de velhos. Quando foi que ele ia seguir a viagem dele de manhã, os veio vieram lá ficar com ele até umas horas da noite.

P: Foi quanto tempo isso, Dona Dejair, que ele ficou aqui?

D: Ele passô por aqui. Ele não ficava dias, não. Máximo três dias aonde que ele ia deixar a fonte benzida.

P: Então ele ficou esses três dias?

D: Ficou esses três dias em Água Grande. Daí os nossos avós vieram, ficaram lá com ele, rezou, ensinou eles cada vez mais, como que era a vida, como que fazia pra se defender, diz ele "Oh, só tem um segredo que esse só o pai sabe, nem o filho sabe”, falou, a mãe velha que contava pra nóis, né? Daí se aprontou uma chuva muito grande, sabe? Essa noite. Ia amanhecer, como de manhã e ele ia seguir a viagem dele pra frente. Se aprontou aquela chuva muito forte e ele 
tava debaixo de uma árvore, com o punhado das coisa dele ali e com o calderãozinho dele que ele fazia o mingauzinho dele, que ele só comia era mingau com couve e pimenta, pimenta daquela ardida. Se aprontou aquela chuva forte, minha avó contava, daí o nosso avô pegou e falou pra ela: "Vamo, Benedita, que vai caí essa chuva, é com vento muito forte". Dava calmario, dava aqueles arrebento feio e foi chegando aquele vento e eles sentaram em volta daquele fogo. Tavam tomando chimarrão, daí ele falô pro vovô "Não filho, pode ficar mais, não tem perigo, não moia" e disse "Mas era bom que o senhor fosse lá na nossa casa porque aqui o senhor vai se molhar de monte", "Podem ficarem vocês aqui", pá, veio aquele mundo de chuva que deitava as copa das árvores, e eles debaixo daquela árvore ali, molhô de roda, onde que eles tavam não molhou, não apagou o fogo e não deu nenhuma goteira, e depois que passou ele dizia "Agora meu filho, agora é vocês é que sabe, agora já passou. Vocês cada vez mais vocês fala assim: Senhor aumentai a nossa fé", daí de manhã ele seguiu o que ele passou, ele passou nas Anta lá, que lá tem o olho d'água dele, passou no Felisberto primeiro e de lá ele foi pras Anta. Nessa época, lendo o primeiro livro que ele deixou, eu inda li um trechinho que fiquei uns cucoco com o... que explicava muita coisa, filha. É nessa época que ele passou, aqui foi em 1912, o profeta São João de Maria passou por cima dessas terra aqui, nessa época (Depoimento de dona Dejair, 30/01/2007).

Do trecho acima, cabe destacar alguns aspectos centrais. Em primeiro lugar, São João de Maria, o "servo de Deus", é um importante agente instaurador do social, pois antes a região era apenas "sertão, mato, mato livre". É ele quem deixa uma fonte de água sagrada. Com sua presença, portanto, a "terra santa" dos ancestrais tem um reconhecimento que transcende os limites do grupo, pois que realizado por alguém de relevância no catolicismo regional - relevância que, assim como no caso da comunidade, não é atribuída pelas autoridades eclesiásticas, mas expressa por seu reconhecimento popular, poder e estilo de vida que adota.

Acrescente-se que São João de Maria não somente permanece próximo ao local de moradia do casal ancestral por três dias, mas convive com eles e lhes transmite ensinamentos. Assim, ele, além de deixar uma fonte sagrada no local, propaga uma postura e uma compreensão de mundo também sagradas. A própria descrição de sua figura e de seus hábitos aponta nesse sentido: apesar de sábio e iluminado por Deus, uma pessoa simples, sem grandes posses ou vaidades, que só se alimentava de mingau com couve e pimenta, dormia ao relento, e estava disposto a compartilhar sua sabedoria e seus poderes com os mais humildes. 
A descrição dos acontecimentos ocorridos durante sua presença em Água Grande descreve como Maurício e Benedita foram por ele protegidos de uma chuva pesada (podemos pensar em que medida tal acontecimento não demonstra a proteção do monge ao casal e ao grupo frente às mudanças que iriam enfrentar) como forma de estimulá-los a aumentar sua fé.

Dona Dejair continua o relato com a descrição de seu encontro com São João de Maria, quando tinha oito anos (o que teria ocorrido por volta do ano de 1949), em que a presença do monge na memória, estimulada pelo desejo de conhecê-lo, se materializa. É importante marcar que o encontro se dá aos pés de uma cruz, situada na divisa da comunidade - aspecto este muito significativo, visto que a fixação de cruzes (seja em locais onde corpos a serem levados ao cemitério descansaram, seja nas proximidades da fonte sagrada, seja no local onde uma das filhas de Benedita morreu nos fogos de 1963 ou, ainda, nas portas das casas) é outro processo relevante de sacralização do território. Nesse caso, o santo abençoa dona Dejair, para em seguida ir embora e não mais voltar, retirando-se, segundo a narrativa, a fim de "descansar" (observe-se que não há registro histórico da morte de nenhum dos monges João Maria; cf. Fachel 1995). Antes, contudo, recomendara o cuidado com as fontes sagradas que deixou, e a persistência na fé, principal fator de proteção e cura.

D: Então, a gente era criança né, eu escutava a mãe veia contá assim, conversa né, iam tomar o chimarrão e conversar, eu falava pra minha mãe que eu queria conhecer "Eu quero conhecer mãe, é santo?". A minha mãe dizia "Filha, é um servo de Deus, é o primeiro servo que Deus enviou pra aconselhar o povo"; "Que jeito que ele é?"; "Ah, um dia a filha vai ver, a mãe também não conheceu", pois ela também nasceu aqui, né, daí eu sempre falava, fui crescendo mais e aquele chãozinha [?] na minha cabeça assim e eu falava pra mãe que eu queria conhecer. Quando eu completei 8 ano meu pai me pôs na escolinha e daí a gente foi estudar, e eu sempre lembrava, passava lá na Água Grande, ia lá e eu pensava, mais eu tinha que vê, pra mim vê quem é, vortava. Oh, eu estudei anos, um ano, dois anos, e eu saí da escola no terceiro ano e eu falava que eu queria conhecer, quando foi um dia meu pai me levou até um arto lá em cima e daí ele falou "Oh, filha, agora o pai vai vortá que o pai tem que trabalhá. O pai ainda vai pro serviço. Daqui a filha vai bem". Eu desci correndo, quando foi chegando perto de uma cruz que tinha, agora não tem mais, na beira da estrada, eu desci correndo e fui lá...

P: Era cruz de gente daqui mesmo dona Dejair?

D: Era, é gente que era da Barra que morreu lá e eles iam levando 
pra Curiúva e aonde eles descansaram na saída desse lugar lá e eles plantaram uma cruz, e neu passá na frente da Santa Cruz eu não enxerguei aquele senhor sentadinho de frente à cruizinha e eu fui, mas daí como criança eu queria conhecer e pelo que a mãe velha contava eu pensava "Mas um dia eu ainda vou conhecer", eu pensava assim, quando eu atendi assim passar assim e eu vi aquele senhor sentado com as perninha assim como tá na imagem dele lá na estante, aquela boininha na cabeça assim tipo um bonezinho, mas sem bico, e aquele era o surrão de erva do, como diz, do chimarrão dele que ele carregava tudo o preparo do chimarrão do lado, daí eu caminhei abeirando do outro lado, daí no eu passar, eu pedi a benção pra ele e ele me abençoou daí ele falou "Filha, não fique com medo porque você queria conhecer". Ai que maravilha tão grande pra mim, mas eu fui indo, sabe, eu fui abeirando assim e eu fui caminhando e atendendo nele e ele olhando ni mim, quando passei pra frente eu arrumei a mão de novo e tornei a pedir a benção e ele me abençoou e falou "Deus que acompanhe, filha, e não tenha medo". Daquela hora, menina, eu ó, eu corri.

P: Mas por que a senhora teve medo dona Dejair?

D: Porque eu era criança! Eu era pequena eu queria ir na escola mas com 8 aninho a memória é... mas daí eu chavei [?] na minha memória, eu correndo e eu pensando "É o santo! É o santo! É o santo!" e daquele jeito eu fui correndo. "Eu vou contá pra mãe! Eu vou contá pro pai! É o santo que a mãe veia Benedita contou. É ele. Porque eu corri?". Aí eu fui pra aula e lá eu fiquei lá, porque eu fui muito chorona sabe? A professora mandava eu ler o $A B C$ e eu chorava porque eu não sabia. Ela ensinava e ensinava, e daí mandava: "Venha aqui, Dejair, venha aqui. Você conhece essa letra aqui?". E eu caía no choro. Eu fui muito assim chorona, mas fiquei lá até o horário dela soltar pra vim embora. Quando foi a tarde o horário que ela soltava todos os alunos, quando eu caí pra fora eu saí correndo em frente de todos os colegas. "Eu vou chegar e vou contar pra mãe. É São João de Maria que a mãe veia conta, contá pra mãe, conta pras outras mãe veia. É ele”. E daí eu vim, um pouco corrido, um pouco caminhava outro pouco corria e cheguei na casa correndo, a mãe levou um susto. Saiu e "O que é isso minha filha, o que é que aconteceu?"; "Mãe, eu vi o santo que a mãe veia conta pra senhora. Madrinha Adelaide, eu vi"; "Que santo, minha filha?"; "Aquele santo que a mãe veia conta que deixou aquele olho d'água lá na serraria", eu falei. Ela disse: "São João de Maria". Eu falei: "É, mãe, eu vi, tava lá sentadinho no pé lá da Santa Cruz daquela 
mulher que morreu". A mãe: "Mas não pode filha, não é, a filha se enganou"; "É, mãe, porque é bem do jeito que a mãe velha conta. É ele, mãe". A mãe falou assim: "É mentira, minha filha, criança gosta de mentir". E eu falei: "Não é, mãe, não é mentira, porque o pai fala que se mentir ele surra, não pode mentir e a senhora fala pra gente. Eu vi". E daí eu fiquei com aquilo no meu sentido, sabe, porque eu queria ver e graças a Deus eu vi. E aí quando foi à noitezinha, meu pai chegou do trabalho, minha mãe contou e meu pai falou "Ai, Maria, você vai acreditar, mulher, numa conversa de criança? Criança você sabe, criança é boba. Às vezes ele era uma pessoa diferente, às vezes era uma pessoa que tava sentado descansando". Mas era o servo que tava lá sentadinho descansando, sim! Porque eu vi! Daí a mãe: "Mas a menina tá que toda hora ela tá falando". O pai disse: "Ah, mas eu não vou acreditar". Daí eu falei: "É verdade, pai, eu vi. É São João de Maria que a mãe velha Benedita conta pra mãe, pra madrinha Adelaide, pra mãe veia, pra Cidinha (que era a mãe do meu pai), pra mãe veia Da Luz, ela fala, eles escutam e conversam pai, eu vi". O pai disse: "É, se viu então...". De certo ele viu que eu fiquei nervosa de falar que era mentira. Óia, passou dali três dia, um senhor lá de Felisberto, uma pessoa de idade contou pra eles que o profeta João de Maria teve no olho d'água, lá no Felisberto e foi pras Anta. Daí lá nas Anta ele ficou mais três dia e encomendou pra pessoa que zelava da fonte, que daí ele ia descansar, disse: "Agora eu vou descansar. Zele da fonte pra vocês ter o remédio, se vocês crer, tiver boa fé, com esse remédio aqui cura qualquer enfermidade, mas tem que acreditar. Tem que ter muita fé que você cura de qualquer enfermidade, que agora eu vou descansar pra sempre, eu vou pra terra do Taió". Fica na Lapa, fica perto de Curitiba, o meu filho mais velho, ele já foi lá. E eu fiquei com aquilo no sentido... (Depoimento de dona Dejair, 30/01/2007).

Nesta longa fala, trecho de uma entrevista de mais de duas horas e meia com dona Dejair, explicita-se como passado e presente estão vinculados através da fé. Fé reforçada pelos ensinamentos de São João de Maria, constantemente atualizada nos ritos periódicos que reúnem toda a comunidade e que fundamenta um modelo de vida e comportamento baseado no respeito à família, às tradições e memórias do grupo, ao ambiente, às obrigações religiosas.

A história narrada por dona Dejair, e reconhecida como verídica e relevante pelos demais membros da comunidade, evidencia seus poderes religiosos e de cura. Com relação a esses poderes, há duas outras histórias significativas. Assim como São João a abençoa, o que não ocorre com nenhuma outra pessoa atualmente 
viva, também sua avó lhe atribui, ainda nova, a responsabilidade de zelar pelas práticas religiosas tradicionais do grupo, entregando-lhe a matraca que deve ser tocada nas recomendas ${ }^{19}$ e que ela guarda consigo ${ }^{20}$.

Posteriormente, em um incêndio que destruiu parcela significativa do Paraná, no ano de 1963, atingindo também Curiúva, as casas de vários moradores locais foram queimadas. Mas, ao perceber o risco que corriam, antes de sair de sua casa dona Dejair rezou em torno da construção: "Eu agradeço a Deus todo dia porque eu peguei meus santos e dei três voltas, dei uma volta em roda [...] e pedi que Deus tomasse conta de nós e de tudo que nós tínhamos" (Depoimento de dona Dejair, 30/01/2007). Sua casa permaneceu então intacta pelo fogo, e eles não tiveram que receber ajuda do governo, pois não ficaram desabrigados e nem perderam os alimentos que haviam colhido.

A importância da presença de São João de Maria nas terras da comunidade, na região denominada Água Grande, faz a expulsão da área - cuja história é conhecida por todos e também está repleta de referências religiosas - ser a grande narrativa de expropriação do grupo. Em primeiro lugar, por ser a expulsa a própria ancestral. Além disso, por ter sido ela enganada por um compadre. De acordo com os relatos, sendo as terras em que viviam tomadas por pinhais - o que justifica, inclusive, o nome de Fazenda Pinhal -, Benedita decidiu vender o pinhal da região de Água Grande para uma serraria que se instalara nas redondezas. Pediu para tanto auxílio ao compadre, dando a ele uma procuração. O compadre, agindo de má fé, aproveitou a oportunidade para vender, juntamente com o pinhal, as terras em que parte significativa da família morava. No local se encontravam a fonte sagrada de São João e a cruz na qual eles faziam orações periódicas, em cujos pés diziam estar enterrada uma criança ${ }^{21}$. Nas palavras de Gentil e Zelão, o primeiro irmão e o segundo primo e genro de dona Dejair:

G: Aqui, minha avó morava aqui pertinho de mim ali, ó, só passa esse capão de mato aqui e era a residência que eles morava, ela vendeu os pinhá pro compadre dela e ele acabou vendendo a terra, sem saber. Quando eles acabaram de cortar o pinhá, eles falaram pra ela: "Agora a senhora tem que se mudar daqui"; "Poxa, mas eu não vendi a terra, vendi os pinhero". Isso eu lembro, que eu já tava grande, ela falava sempre assim "Eu não sei o quê que aconteceu com a nossa famia que careceu saí de lá, saímo expurso, saímo tocado de lá e mudaro nós pra cá”. E daí, logo mais, fizero aquela divisa lá e jogaram nós pra aquele canto, vorta e meia tomava mais um pedaço né, expursando nós lá pro fundo e nós sem beco, sem saída. Como tamo até hoje se vocês verem aqui é um aperto pra cada um. Oh o trechinho que eu moro aqui, é um trechinho que eu tinha lá né22. 
$[\ldots]$

P: E da venda dos pinheiros não teve documento? Também, nada?

G: Pois é, isso aí eu não posso contar pra vocês por que eu não sei se ela recebeu um recibo desse aí ou não recebeu. Mas eu acho que não recebeu foi nada.

Zão: Só pra prolongar o que o Gentil ia dizendo dos pinhá que o Zé contava várias vez, o Gentil sabe disso. O pinhá diz que foi assim, esse I., né, esse I. era compadre de nossa vó.

G: Bisavó, né?

Zão: É, bisavó. Daí ele chegou na casa dela pra tomar café não sei o quê, aquela coisa, e daí pegou e: "Viu compadre, eu tou querendo vender o pinhá". Que aqui tudo, lá pra Água Morna, que aqui é considerado Água Grande né, mas é o mesmo bairro, aí aqui tudo até o Rio das Antas, isso aqui era tudo pinhá, aqui macaco pulava de um gaio no outro, aí nos pinheiro. [...] Então quando ela abriu a boca dizendo pra ele foi um prato cheio, quando ela abriu a boca dizendo que queria vender o pinhá, ele falou: "Comadre, eu pego o pinhá pra vender pra senhora". Agora, ela era uma pessoa humilde, pessoa que não conhecia nada e ele muito inteligente, pegou, saiu, foi pra Curiúva, lá fez e quis desfazer lá e aí vendeu as terra junto com o pinhá. Aí quando ela menos esperou chegou, chegou o I., o I. com cara de quem comprou o pinhá e a terra junto. E daí entregaro documento pra ela assinar, pra ela assinar o documento, daí ela assinou o documento e daí dali um pouco já entraro invadindo né. G: Invadindo.

Zão: Invadindo dizendo que tinham comprado. "Não, mas aqui eu vendi o pinhá", "Não, a senhora vendeu, a senhora... tá aqui a assinatura da senhora", e ela não entendia a assinatura, não conhecia nada, era uma coitada...

G: Era uma coitada.

Zão: Era uma coitada, não entendia nem qualquer letra, ela não conhecia. Pronto, aí foi a hora que eles foram invadindo, foram invadindo e jogando embora, foram empurrando pros canto assim. G: Foram medindo a quantia que quiseram, né.

Zão: A quantia que quiseram. (Depoimentos de Gentil e Zelão, 06/ 02/2007).

O processo de expulsão, que já é absurdo, torna-se ainda mais sério por ter sido feito por um compadre. Assim, não somente são expulsos de um solo sagrado, mas o agente responsável por isso é alguém que deveria saber respeitar a condição, na medida em que se unia ao grupo também através de laços 
sagrados. Por outro lado, o pai de dona Dejair, que trabalhava no corte do pinhal (como outros membros do grupo), dedicou parte de seu pagamento para adquirir a madeira com que construiu a igreja que hoje se situa no lugar da antiga cruz. Mesmo após a expulsão da área, os membros da comunidade continuaram ainda por um tempo a frequentar a igreja. Mais recentemente, com a presença dos carismáticos no local, passaram a sofrer forte discriminação no templo, o que os levou a desistir de frequentar o local - consistindo essa em uma segunda expropriação. Decidiram, então, construir sua própria igreja, em um terreno que hoje é deles.

Dona Dejair também é a portadora, na atualidade, da maior "mãe" do remédio sagrado denominado "Vinagre de Bom Jesus"². Esse remédio é mais uma expressão da religiosidade particular do grupo, e valorizado não somente por seu potencial curativo, mas por ter sido trazido pela mãe velha Benedita de suas andanças antes de chegar no local. Ele é normalmente utilizado em problemas digestivos, principalmente de crianças, e possui características muito específicas. Em primeiro lugar, a sobrevivência do remédio depende da fé de quem o possui - pois a ausência de fé implica na impossibilidade do crescimento da muda, que vai gerar uma nova "mãe". Depois, ele não pode ficar exposto em local visível a todos, nem ser pego com a mão esquerda, ou pelo fundo da garrafa. Além disso, a "mãe" de dona Dejair é proveniente da única coisa que restou do incêndio da casa de seu pai quando ela era menina.

O incêndio é outro caso significativo de expropriação. Teria sido provocado por um homem que disse ao pai ter comprado as terras. Ele, desconfiado, foi visitar o sogro (que era neto de Benedita e havia cedido o terreno para a família do genro) para resolver a questão, mas ao voltar encontrou a casa toda queimada. O episódio provocou a mudança definitiva da família para perto do sogro, em Água Grande - de onde, como vimos, eles também seriam expulsos pouco tempo depois. A única coisa que restou foi o vidro do vinagre. Nas palavras de Gentil:

G: O meu pai morava lá, para o lado de lá da estrada, no fundo, beirando uma água que tem lá [o Rio das Antas, segundo Zelão]. Daí ele pegou e saiu para passear na casa do sogro dele, que é meu avô, e aconteceu que ele chegou lá na casa e estava queimada. Mas antes, a pessoa que falou que tinha comprado lá, tinha falado para ele que ele tinha que sair de lá, porque ele tinha comprado e tinha que desocupar. Tinha comprado do Marcos Ferreira [o mesmo que ficou com o terreno do Pinhal]. Daí ele disse: "Não, eu não vou sair daqui, pois aqui meu sogro me deu para mim morar aqui, como é que eu vou sair daqui?". Ele pegou e saiu de lá para vir na casa do sogro dele para contar o assunto, como ele contou mesmo, daí quando voltaram estava queimada a casa. [...] Daí ficou aquele 
cinzeridão, a mãe começou a fuçar lá e achou o vidro de vinagre. Encolheu. Até poucos anos ainda tinha ele. Daí com o calor do fogo ele foi achatando assim e ficou só um pote... era vidro.

Z: E não estourou!

G: Daí ela deu um pouquinho para cada um de nós quando ela foi ficando velhinha. Deu um pouco para a comadre Deja, deu um pouco para mim... Continuou funcionando. E nós temos aí, ainda tem. Do tempo da minha mãe! É desse vidro, e até hoje não acabou. É aquele que eu estava contando para você que eu dou para os meus netinhos quando dói a barriga... Daí o meu pai veio ali na casa do sogro dele, fizeram um ranchinho lá, parou na casa do sogro primeiro para poder fazer um rancho para poder mudar... Perdeu tudo. Daí o veio pegou, socorreu ele, ajudou ele, fizeram um outro ranchinho para ele parar. Mas parava com o veio daí até fazer outra morada. Mas aconteceu isso aí.

(...)

G: Devido que o vinagre a mãe conseguiu dos avôs deles. E eu vou falar a verdade que eu nem sei onde foi que eles conseguiram. A mãe dizia que era do Senhor Bom Jesus da Lapa ${ }^{24}$. Mas já era a bisavó que tinha trazido, e quando eles apareceram por aqui ela já tinha, e daí tudo eles conseguiram. E nós temos até hoje esse vinagre. Uma dor no estômago, uma dor na barriga, você toma e dali a pouco espalha tudo... (Depoimentos de Gentil e Zelão, 06/02/ 2007).

Novamente, os vínculos comunitários e a religiosidade profunda do grupo são recompensados com a possibilidade de manutenção do remédio duplamente sagrado: por ser de Bom Jesus e por ter sido trazido pela ancestral. Se o incêndio os expulsara da terra, não lhes privara do poder curativo de Bom Jesus.

A expulsão adquire um caráter ainda mais profanador pela história, cujo cenário é a casa do Rio das Antas, relatada por dona Dejair sobre o irmão imediatamente mais novo. Ele morreu logo depois de nascer, e seu corpo teria sido velado no local, envolto em mortalha de papel devido à impossibilidade da família de the providenciar uma vestimenta mais adequada. O sepultamento ocorreu na localidade de Felisberto. Cerca de dois anos mais tarde, aconteceu o incêndio. Passado algum tempo, nhô Anísio, um dos donos da área do Pinhal também expropriada, passou pelo cemitério e viu um vaso de flor. Foi conferir e identificou a sepultura do irmão natimorto de dona Dejair. Ao se aproximar, encontrou o caixãozinho do menino aberto, com o corpo intacto. Havia virado "corpo santo". Dizem que ele foi mandado a Roma. No entanto, não contaram para os pais da criança o que havia acontecido, dizendo que eles poderiam ficar 
excessivamente orgulhosos por ter um filho santo. Quando, passado tempo, os pais souberam do ocorrido, ficaram felizes, mas também chateados por não terem sido avisados antes. Novamente, são eles, negros , pobres ao ponto de precisarem fazer uma mortalha de papel, que são agraciados com um filho santo, e são os então poderosos, devido a processos ilegítimos de conquista de terra, aqueles que se recusam a reconhecer a sacralidade da comunidade.

Os relatos acima são apenas alguns indícios de como a comunidade de Água Morna, a fim de responder às recentes demandas externas em torno da elaboração de uma identidade quilombola, mobilizam memórias e práticas preexistentes, e dessa forma acabam por reforçar alguns aspectos dessa memória e dessas práticas, lendo o novo jogo político a partir de uma perspectiva já compartilhada pelo grupo. Podemos pensar, aqui, na discussão de Sahlins (1997a; 1997b), quando o autor argumenta que os enfrentamentos de novos contextos, mesmo que envolvendo processos de dominação e imposição de modelos externos, podem ser encarados pelos grupos como oportunidades para fortalecerem sua cultura e sua organização social. Embora seja importante reconhecer que nem sempre isso aconteça, podendo haver mesmo uma desestruturação de alianças, práticas e concepções que dão sustentação ao grupo, não é possível, antes da análise dos casos concretos, compreender de que maneira as distintas comunidades quilombolas vão lidar com o reconhecimento de seus direitos legais e as exigências discursivas e de organização social a ele vinculadas.

No caso específico tratado aqui, talvez se possa dizer que o projeto - como são conhecidas as diversas ações de agentes estatais, mesmo que não diretamente relacionadas - serve como instrumento para recuperar memórias significativas, bem como respaldar a apreensão religiosa profética do mundo. Portelli (1997), ao refletir sobre a ansiedade do historiador oral pelo retorno de seu trabalho àqueles que entrevista, afirma que a própria possibilidade de ter uma escuta legítima e legitimadora de seu relato, de organizar de forma sistemática o discurso sobre o passado, e de ver inscrita sua versão da história - normalmente desconsiderada - em fontes oficiais podem ser retornos muito relevantes para os sujeitos. Também Chagas (apud Leite 2005) ressalta como, para os membros da comunidade de Morro Alto, fazer sua voz ser ouvida como conhecimento relevante sobre a história, bem como ser valorizado na construção da nação, é tão significativo como ter a possibilidade de seus direitos territoriais garantidos.

Para os componentes do que chamei o núcleo central de Água Morna, parece-me que a perspectiva, mesmo que remota, de retomada das terras que um dia pertenceram a seus ancestrais, acompanhada pelo reconhecimento da validade de seus relatos sobre o passado e a expropriação por eles sofrida, bem como de sua religiosidade - e, indiretamente, da sua legitimação como mais sólida inclusive que a de não membros do grupo - é vista, em si mesma, como um ganho. $\mathrm{O}$ projeto os transforma, de pequenos produtores mal-sucedidos - 
pois que hoje espremidos "que nem farinha no tapiti" - em pessoas declaradamente expropriadas, portadoras de direitos e de conhecimentos, dignas de respeito e admiração. A situação precária em que viviam, arrendando terras distantes, enfrentando trabalhos abusivos para fazendeiros da região, é transformada pelo horizonte de uma nova condição para a comunidade. Condição que, em última instância, reforça a previsão dos ancestrais e consolida-os como um povo "protegido por Deus". Por fim, as ações de compadres traidores, de católicos intolerantes da Renovação Carismática, ou de moradores das vizinhanças que confundem as recomendas com atos de feitiçaria poderão ser devidamente respondidas. A identidade quilombola é, neste caso, uma oportunidade valorizada de modificar o lugar social da comunidade, o que pode ser feito a partir da renovação e da articulação de elementos que ela mesma considera relevantes.

\section{Referências Bibliográficas}

ARRUTI, José Maurício. (1997), "A emergência dos 'remanescentes': notas para o diálogo entre indígenas e quilombolas". Mana, vol. 3, nº 2: 7-38.

. (2006), Mocambo: antropologia e história do processo de formação quilombola. Bauru: EDUSC. (2007), "Uso comum, regularização fundiária e mercado de terras: estudo de caso na comunidade do Cangume (Vale do Ribeira - SP)". In: BRASIL. Prêmio Territórios Quilombolas (2 ${ }^{a}$. Edição). Brasília: Ministério do Desenvolvimento Agrário.

BRAGA, Geslline. (2009), Retratos da benção: usos da fotografia entre as benzedeiras de Campo Largo. Curitiba: Dissertação de Mestrado em Antropologia Social, UFPR.

BRASIL. (1988), Constituição da República Federativa do Brasil. Brasília: Senado Federal. (2001), Decreto Presidencial 3912/2001. Brasília: Presidência da República/ Casa Civil. (2003), Decreto Presidencial 4887/2003. Brasília: Presidência da República/ Casa Civil.

CABRAL, Osvaldo R. (1960), João Maria: interpretação da campanha do Contestado. São Paulo: Companhia Editora Nacional.

FACHEL, José F. (1995), Monge João Maria: recusa dos excluidos. Porto Alegre/ Florianópolis: Ed. UFRGS/ UFSC.

FRAGA, Nilson C. (2009), Contestado: o território silenciado. Florianópolis: Insular.

GALLO, Ivone C. D’Ávila. (2008), "Profetismo popular na guerra do Contestado". In: M. Espig \& P. Machado (orgs.). A guerra santa revisitada: novos estudos sobre o movimento do Contestado. Florianópolis: UFSC.

LEITE, Ilka B. (2005), Laudos periciais antropológicos em debate. Florianópolis: NUER/ABA.

MACHADO, Paulo P. (2004), Lideranças do Contestado: a formação e a atuação das chefias caboclas (1912. 1916). Campinas: UNICAMP.

MARCON, Telmo. (2008), "Cultura e religiosidade: a influência dos monges do contestado". In: M. Espig \& P. Machado (orgs.). A guerra santa revisitada: novos estudos sobre o movimento do Contestado. Florianópolis: UFSC.

MARTINS, Wilson. (s.d.), Um Brasil diferente. São Paulo: T. A. Queiroz Editor.

NUER. (1997), Boletim informativo NUER: regulamentação de terras de negros no Brasil, vol. 1, no 1 . (2005), Boletim informativo NUER: territórios quilombolas - reconhecimento e titulação das terras, vol. 2, no 2 .

. (2006), Boletim informativo NUER: quilombos no sul do Brasil - perícias antropológicas, vol. 
3, no 3 .

PORTELLI, Alessandro. (1997), "Tryin' to Gather a Little Knowledge: Some Thoughts on the Ethics of Oral History". In: A. Portelli. The Battle of Valle Giuli. Madison: The University of Wisconsin Press. PORTO, Liliana. (2007), A ameaça do outro: magia e religiosidade no Vale do Jequitinhonha/MG. São Paulo: Attar.

. (et al.) (2009), Relatório antropológico: comunidade quilombola de Água Morna - Curiúva/PR (documento resultante do Convênio UFPR/INCRA com base no projeto "Direito à terra e comunidades quilombolas no Paraná"). Curitiba: UFPR/INCRA.

RIOS, Ana Lugão \& MATTOS, Hebe (orgs.). (2005), Memórias do cativeiro: família, trabalho e cidadania no pós-abolição. Rio de Janeiro: Civilização Brasileira.

ROSA, Míriam V. R. (2004), Espinho: a desconstrução da racialização negra da escravidão. Brasília: Thesaurus.

SAHLINS, Marshall. (1997a), "O 'Pessimismo Sentimental' e a Experiência Etnográfica: Por que a Cultura não é um 'Objeto' em Vias de Extinção - Parte I”. Mana, vol. 3, no 1: 41-73.

(1997b), "O 'pessimismo sentimental' e a experiência etnográfica: por que a cultura não é um 'objeto' em vias de extinção - parte II”. Mana, vol. 3, nº 2: 103-150.

\section{Notas}

1 Atualmente, esta é a maneira como o grupo se define. No passado, contudo, relatam que eram conhecidos como Bairro (Rural) de Água Morna.

2 Acreditamos que, apesar de todas as críticas que a atuação da Secretaria e as modificações necessárias para a aprovação do Estatuto possam sofrer, estes são indícios de que as relações raciais estão na pauta política atual de maneira inquestionável.

3 Aqui, o parágrafo com o qual Wilson Martins finaliza seu livro Um Brasil Diferente, publicado pela primeira vez em 1955, ilustra bem esta perspectiva: "Assim era o Paraná. Território que, do ponto de vista sociológico, acrescentou ao Brasil uma nova dimensão, a de uma civilização original construída com pedaços de todas as outras. Sem escravidão, sem negro, sem português e sem índio, dir-se-ia que a sua definição humana não é brasileira. Inimigo dos gestos espetaculares e das expansões temperamentais, despojado de adornos, sua história é a de uma construção modesta e sólida e tão profundamente brasileira que pôde, sem alardes, impor o predomínio de uma ideia nacional a tantas culturas antagônicas. E que pôde, sobretudo, numa experiência magnífica, harmonizálas entre si, num exemplo de fraternidade humana a que não ascendeu a própria Europa, de onde elas provieram. Assim é o Paraná. Terra que substituiu o sempre estéril heroísmo dos guerreiros pelo humilde e produtivo heroísmo do trabalho quotidiano e que agora, entre perturbada e feliz, se descobre e si mesma e começa, enfim, a se compreender" (Martins s.d.:446).

4 Este aspecto nos foi apontado pela colega Christine Chaves. É curioso observar que o citado deslocamento foi realizado de forma tão bem sucedida que é tomado como dado pela maioria dos autores, entre os quais me incluía.

5 A titulação coletiva exige uma reflexão aprofundada que, contudo, foge ao escopo deste texto. Cabe apenas marcar nossa opinião de que, por um lado, é um importante instrumento para que a regularização fundiária não resulte em uma estratégia de inserção das terras ocupadas por quilombolas no mercado de terras (cf. Arruti 2007). Entretanto, por outro lado, é um elemento que traz resistência significativa de diversos grupos quilombolas (ou de segmentos dentro dos grupos), por compreenderem que esta forma de titulação implicaria necessariamente em um igualitarismo e um uso totalmente compartilhado do território - desconhecendo diferenciações internas hoje existentes, bem como a prática recorrente de que, mesmo em casos de territórios de uso comum, parcelas dele sejam usadas e/ou controladas por grupos familiares específicos. 
6 Como referências para uma discussão mais detalhada e complexa da questão legislativa, consultar Arruti (2006), bem como os três números do Boletim Informativo do NUER (1997, 2005 e 2006).

7 Esta nova conceituação do sujeito de direito do art. 68 implica, por sua vez, no fortalecimento do antropólogo como especialista com papel de relevo na consolidação do processo de titulação, na medida em que, no parágrafo $2^{\circ}$ do artigo citado serão consideradas terras ocupadas por estes grupos aquelas "utilizadas para a garantia de sua reprodução física, social, econômica e cultural". Em outras palavras, o reconhecimento do grupo como caracterizado por uma alteridade sócio-cultural e econômica contemporaneamente identificada traz para o horizonte da disputa de direitos o antropólogo como profissional com formação legítima na abordagem da alteridade.

8 Em texto posterior, pretendemos discutir em maiores detalhes como este estereótipo de comunidade se conjuga tanto com o histórico da inserção da noção de comunidade no mundo rural brasileiro a partir da atuação da Igreja Católica - que traz em si um modelo de "comunidade cristã" - quanto da tradição das próprias ciências sociais - em que a ideia de comunidade é geralmente construída em contraposição à de sociedade, ressaltando aspectos como: pouca diferenciação interna, um tipo de solidariedade com base na igualdade, ausência de conflitos e projetos políticos diferenciados, entre outras características. Duas tradições, portanto, que concebem a comunidade a partir de uma perspectiva romantizada.

9 Estas certificações são expedidas pela Fundação Cultural Palmares, e exigidas pelo INCRA para que o procedimento de regularização fundiária seja iniciado.

10 Significativa é a fala de um morador da comunidade de Guajuvira, que vem se destacando como liderança local, de que antes do projeto nunca ouvira falar de quilombo, a não ser na novela "Escrava Isaura" (em que uma escrava branca é a heroína injustiçada da trama exatamente por conjugar as características de escrava e branca). Esta fala demonstra como a identidade elaborada é imputada do exterior.

${ }^{11}$ Para tanto, acreditamos que também contribuiu o impacto da ação do próprio grupo e o lugar político e econômico que o agronegócio ocupa no Paraná.

12 Segundo informação pessoal do presidente do grupo.

${ }^{13}$ Usamos aqui o termo "devoção" por não encontrarmos outro melhor, embora reconheçamos não ser ele o mais adequado. Com efeito, a relação das populações caboclas ou sertanejas, como as denominam os estudiosos, com São João (de) Maria não se dá apenas a partir de uma lógica clara de santificação, mas sim de compartilhamento de uma realidade e compreensão do mundo com a pessoa do monge. Assim, as grandes referências são a sua memória (seja através de relatos de antepassados ou de experiências dos próprios narradores), as curas, os ensinamentos e as profecias a ele atribuídos. Exemplo disto é o local em que está sua fotografia na casa de dona Dejair, líder religiosa de Água Morna: não entre as imagens sagradas ou no altar, mas na estante da sala que reúne as fotos dos familiares (embora em contextos como das benzedeiras de Campo Largo, estudadas por Braga (2009), a foto se localize normalmente no altar).

${ }^{14}$ A Comunidade de Guajuvira, distante $15 \mathrm{~km}$ de Água Morna, possui muito mais dissensões internas e conflitos externos, além de apresentar uma resistência explícita à presença da interferência estatal em seu território, o que se deve, além de a sua organização social, à experiência dos ancestrais como africanos livres (em que a vivência da escravidão se dá a partir do controle estatal).

${ }^{15}$ Estas casas são menos centrais que as posteriores.

${ }^{16}$ Este relato será analisado posteriormente.

${ }^{17}$ A história dos ancestrais antes da fixação no território é uma história de errância. Assim, eles caminhavam com balaios na cabeça, só parando quando se fixaram na região chamada Água Grande. Não há qualquer memória de sua origem, e o casal se conheceu e casou ao longo de suas andanças.

${ }_{18}$ Os descendentes de dona Pedra (como é chamada Pedrolina) afirmam ser ela ainda mais velha, devido a uma alteração da data de nascimento no momento de realização do registro civil, realizado quando ela já era adulta.

19 Recomendas são rituais de "recomendação das almas" realizados na quaresma, em que membros do 
grupo saem em conjunto rezando em cruzes de mortos e nas portas das casas (que eram marcadas por cruzes). São feitos às quartas e sextas-feiras, ao longo da noite, e devem percorrer um número ímpar de casas/cruzes, sempre acima de sete locais. O ritual solene é relatado também em outras comunidades quilombolas do estado, como Guajuvira (também em Curiúva) e João Surá (em Adrianópolis), às vezes como ritos do presente, outras como uma expressão do passado.

${ }^{20}$ É importante ressaltar que esta avó é descrita como índia, mas sua forte religiosidade é claramente católica. Aventamos a possibilidade de que ela tenha tido algum vínculo com o aldeamento de São Jerônimo, situado, no século XIX, em região próxima àquela em que está a comunidade de Água Morna.

${ }^{21} \mathrm{O}$ relato de sepultamento de criança aos pés de uma cruz também aparece em Guajuvira, e constitui, ao que tudo indica, um processo importante de sacralização da cruz em questão.

22 Aqui é importante esclarecer que Gentil morava na região de Água Morna há poucos anos atrás. No entanto, devido a problemas com o acesso à água, ele propôs ao proprietário que atualmente ocupa Água Grande a troca de seu trecho de terras por aquele em que reside agora, também em Água Grande. Neste sentido, é interessante ressaltar que ele mesmo justifica a troca afirmando que mudou de local, mas não saiu das terras da comunidade, pois foi para mais perto de onde sua bisavó Benedita morava inicialmente.

23 Aparentemente, pelo processo de cultivo do vinagre e o cheiro da solução em que ele fica imerso, o remédio é o resultado da fermentação de água adoçada por um organismo que cresce, formando uma massa marrom, denominada "mãe" do remédio. Na medida em que a solução vai sendo consumida, é necessário completá-la com água adoçada. A "mãe" de dona Dejair foi doada a ela por sua própria mãe, quando ela se casou, e fez o mesmo com suas filhas. Nice, atualmente, também tem uma garrafa preparada para sua única filha, Simone, já com mais de 20 anos. Curiosamente, ela perdeu sua "mãe", mas não preparou outra para si mesma.

${ }^{24}$ Dona Dejair localiza a origem do "Vinagre de Bom Jesus" no santuário de Iguape, e não da Lapa. No entanto, o relato de Gentil seria mais coerente com o discurso de que Benedita teria vindo da Bahia.

Recebido em abril de 2010 Aprovado em abril de 2012

Liliana Porto (lilianaporto@hotmail.com)

Professora adjunta do Departamento de Antropologia da UFPR. Coordenadora da equipe responsável pela elaboração dos relatórios antropológicos das Comunidades Quilombolas de Água Morna e Guajuvira - Curiúva/PR - em convênio UFPR/INCRA.

Carolina Kaiss (carokaiss@yahoo.com.br)

Mestre em Antropologia pelo PPGAS/UFPR. Membro da equipe responsável pela elaboração dos relatórios antropológicos das Comunidades Quilombolas de Água Morna e Guajuvira - Curiúva/PR - em convênio UFPR/INCRA.

Ingeborg Cofré (ingecofre@yahoo.com.br)

Bacharel em Ciências Sociais pela UFPR. Membro da equipe responsável pela elaboração dos relatórios antropológicos das Comunidades Quilombolas de Água Morna e Guajuvira - Curiúva/PR - em convênio UFPR/INCRA. 


\section{Resumo:}

Sobre solo sagrado: identidade quilombola e catolicismo na comunidade de Água Morna (Curiúva, PR)

O reconhecimento de direitos coletivos a comunidades quilombolas abriu caminho nas cenas políticas nacional e regional para a participação de comunidades negras que muitas vezes não possuíam qualquer visibilidade para além de seu âmbito local. Esses grupos precisaram se organizar e elaborar um discurso estruturado sobre sua identidade e direitos que se encaixasse nas demandas estatais, respondendo de formas distintas ao novo contexto - havendo inclusive casos de rejeição ao processo de regularização fundiária. Nesse quadro, a comunidade de Água Morna, localizada no estado do Paraná, vem respondendo de maneira positiva a tal demanda, suscitando a reflexão em torno das bases sobre as quais constrói sua identidade e a história de sua relação com o território, a partir da mobilização das práticas religiosas populares consolidadas no grupo. A proposta deste texto é analisar de que maneira se dá essa mobilização.

Palavras-chave: comunidades quilombolas, identidade, território, catolicismo.

\section{Abstract:}

On Holly Land: Quilombola Identity and Catholicism in the Água Morna Community (Curiúva, PR)

The acknowledge of Quilombola communities' collective rights brought Black Communities forward to the national and regional political scenes. Those communities were, otherwise, very often invisible outside the local sphere. This new situation conducted those communities to both organize and create to themselves a structured discourse about their own identity and rights in order to fit for the political demands. This circumstance led them to search for many different answers with the purpose to become adequate to this new context - some of them even reject the land regularization process. Notwithstanding, Água Morna community shows some answers that leads one to think about the basis over which their identity is constructed and about their relationship with the land. In order to cope with this new situation, it uses solid group's popular religious practices. The aim of the present paper is to analyze the ways in which this mobilization occurs.

Keywords: quilombola communities, identity, territory, catholicism. 